\title{
Euryhapsis fuscipropes sp. n. from China and Tokyobrillia anderseni sp.n. from Tanzania, with a review of genera near Irisobrillia Oliver (Diptera : Chironomidae)
}

\author{
O.A. Sæther ${ }^{1}$ \\ X. Wang ${ }^{2}$
}

Keywords : Diptera, Chironomidae, systematics, Brillia group, Euryhapsis, Tokyobrilia, Irisobrilla, Pseudobrilla, China, Tanzania.

The generic diagnosis of Euryhapsis Oliver and the description of E. cillum Oliver are augmented. E. fuscipropes sp.n. is described as male imago and shown to be close to $E$. cilium. The systematic position of the genera related to Brillia Kieffer and Eurycnemus van der Wulp is discussed. A review and a key to male and female imagines of genera of the Brillia group with single gonostyli are given. The generic diagnoses of the genera Irisabrillia Oliver, Tokyobrillia Kobayashi \& Sasa, and Pseudobrillia Niitsuma are augmented or emended. The description of the female imago of $T$. longicosta Oliver is augmented. T. anderseni $\mathrm{sp}$. $\mathrm{n}$. from Tanzania is described as male and female imago, the description of the male imago of $I$. Tamamegaseta augmented and the female described. The description of the male imago of $P$. komorii Niitsuma is augmented.

Euryhapsis fuscipropes n. sp. de Chine et Tokyobrillia anderseni n. sp. de Tanzanie, avec une révision des genres proches d'Irisobrillia Oliver (Diptera, Chironomidae)

Mots clés : Diptera, Chironomidae, systématique, groupe Brillia, Euryhapsis, Tokyobrillia, Irisobrillia, Pseudobrillia, Chine, Tanzanie.

La diagnose générique d'Euryhapsis Oliver et la description de E. cilium Oliver sont complétées. L'imago mâle de $E$. fuscipropes n.sp. est décrit ; il est proche de $E$. cilium. La position systématique des genres proches de Brillia Kieffer et Eurycremus van der Wulp est discutée. Une révision et une clé des imagos mâle et femelle des genres du groupe Brillia avec un gonostyle simple sont données. Les diagnoses des genres Irisobrillia Oliver, Tokyobrillia Kobayashi \& Sasa et Pseudobrillia Niitsuma sont complétées ou émendées. La description de l'imago femelle de $T$. longicosta Oliver est précisée. Les imagos mâle et femelle de $T$. anderseni $\mathbf{n}$.sp. de Tanzanie sont décrits, la description de l'imago mâle de $I$. Tamamegaseta est complétée et l'imago femelle est décrit. La description de l'imago mâle de $P$. komorii Niitsuma est complétée.

\section{Introduction}

In recent years a number of new genera have been described within the primitive Orthocladiinae ; i.e. Tokunagayusurika Sasa (1978), Euryhapsis Oliver (1981), Xylotopus Oliver (1982), Plhudsonia Sæther (1982), Irisobrillia Oliver (1985), Tokyobrillia Kobayashi \& Sasa (1991) and Pseudobrillia Niitsuma (1991). Tokunagayusurika is closely related to

1. Museum of Zoology, University of Bergen, N-5007 Bergen, Norway.

2. Department of Biology, Nankai University, Tianjin, 300071 P.R. China.
Propsilocerus Kieffer and these genera will be treated in a forthcoming paper. Plhudsonia is related to Diplocladius Kieffer as confirmed in a recent paper (Sæther 1992). The remaining genera are related to Brillia Kieffer and Eurycnemus van der Wulp. (Sæther 1977, 1989).

The generic diagnosis of Euryhapsis is augmented here and a new species $E$. fuscipropes described.

The genera Irisobrillia, Tokyobrillia and Pseudobrillia differ from other members of the Brillia group, i.e. Brillia, Xylotopus, Austrobrilla Freeman, Xylotopus, Eurycnemus and Euryhapsis, in having single gonostyli. They apparently form a group 
of closely related genera and the two latter genera should perhaps be regarded merely as a subgenera of the former, A new species from Tanzania, Tokyobrillia anderseni sp.n., is described here, and a review of the genera of the Brillia group with simple gonostyli given.

\section{Methods and terminology}

The material measured was mounted on slides in Canada-balsam following the procedure outlined in Sæther (1969: 1).

The general terminology follows Sæther (1980, 1990). The counts of setae on the wing veins include both dorsal and ventral setae, setae which stands at the margin of a vein are regarded as belonging to the vein.

In the figures of the male genitalia the dorsal view is shown to the left, the ventral aspect and the apodeme to the right. The measurements are given as ranges followed by a mean when four or more measurements are made, followed by the number measured in parentheses (n).

The types are placed in the collection of the Museum of Zoology, Bergen, Norway (ZMB), in the collection of Xinhua Wang, Nankai University, Tianjin, China (ZW) or in the collection of Tadashi Kobayashi, Kawasaki, Japan (TK). Additional paratypes have been deposited in the Canadian National Collection, Ottawa, Canada (CNC) and at Zoologisches Staatssammlung, Munich, Germany (ZSM).

\section{The genus Euryhapsis Oliver}

Euryhapsis Oliver 1981 : 711. Type species Euryhapsis cilium Oliver, 1981 (original designation).

Diagnosis

As in Oliver (1981) with the following additions : Male antenna with groove beginning on flagellomere 3 , sensilla chaetica on flagellomeres 2-4 and ultimate. Third segment of maxillary palp with 2 very long lanceolate sensilla clavata at apex.

Tergite IX of female genitalia without posterior emargination, but with two setigerous protrusions. All three seminal capsules with common opening, the median one thin-walled.

\section{Systematics}

The genus Euryhapsis apparently form the sistergroup of Eurycnemus (Oliver 1981, Sæther 1989) and belongs in the same group as Brillia, Xylotopus, Austrobrillia, Irisobrillia, Tokyobrillia and Pseudobrillia i.e. the Brillia group. The similarities between between these genera may to a large extent consist in symplesiomorphies. As mentioned by Oliver (1985:1106), a likely symplesiomorphy is the superior volsella which is unique within Orthocladiinae, except for Plhudsonia, Tokunayusurika and perhaps Chasmatonotus Loew, having a similar volsella. The absence of a similar volsella would, however, constitute a synapomorphy for the remaining orthoclads. The very long and oblique RM crossveins, however, appear to be a unique synapomorphy for the Brillia group.

Sæther (1992) suggested that the reduced third seminal capsule with separate duct and opening and the common opening of the ducts of the two normal capsules was a unique synapomorphy between Plhudsonia and Diplocladius. However, as shown below also Tokyobrillia shows the same configuration of the spermathecal system. In Euryhapsis the three ducts open together, but with the one leading from the thin-walled median capsule quite similar to Plhudsonia and Tokyobrillia. Also in Xylotopus the median capsule is slightly reduced. The shape of the spermathecal system thus may be a synapomorphy for the Brillia group plus Diplocladius and Plhudsonia, with secondary loss of a seminal capsule in Brillia and Pseudobrilia, Sether (1979, Fig. 7) illustrated a South American female described as Spaniotoma (Orthocladius) eurycnemoides Edwards and placed it in Psectrocladius because of the large pulvilli, lack of acrostichals and genitalia very similar to Psectrocladius, except for the spermathecal system. The similarities of the genitalia of Euryhapsis and Tokyobrillia to those of Psectrocladius now makes it likely that also this species belongs in the Brillia group, and not in Psectrocladius. The species has a conspicuous black ornamentation on thorax, abdomen and legs common in the Brillia group, but not found in Psectrocladius. It probably belong to Eurycnemus, which possesses well developed pulvilli.

\section{Euryhapsis cilium Oliver}

\section{Euryhapsis cilium Oliver 1981 : 714.}

Material studied: Paratypes $\sigma, \varnothing$ : Canada, Northwest Territories, Harris River, 24.VI.1972, F.W.I. Pipeline Project (ZMB). 


\section{Description}

Male imago

As in Oliver (1: $81:: 714$ ) with the following additions : Wing wit netae on Sc, RM, M and Piu ; $R$ with 23 setae, $R_{1}$ with $32, R_{4+5}$ with $38, M_{1+2}$ with $57, \mathrm{M}_{3+4}$ w th 38 , Cu with $2, \mathrm{Cu}_{1}$ with 20 , and An with 15 setae. Wing membrane without setae in cell $\mathrm{m}$ basally of $\mathrm{RM}$.

Female imago

As in Oliver (19 $91: 75$ ) with the following additions : Antennal ra tio 0.40. Flagellomeres length (in $\mu \mathrm{m}): 105,60,60,64,113$.

Wing with 2 set an on brachiolum, Sc with 13 setae, costal extens on with 8 non-marginal setae, $R M$ with $3, R$ with $: 8_{v} R_{1}$ with $78, R_{4+5} 98, M$ with $6, \mathrm{M}_{1+2}$ with $93, \mathrm{~N} \quad 3+4$ with $90, \mathrm{Cu}$ with $45, \mathrm{Cu}_{1}$ with 36 , Pcu with $5 \quad$, and An with 60 setae. Wing membrane with $20 \mathrm{~s}$ tae in cell $\mathrm{m}$ basally of RM.

Hind metatarsus wit 16 sensilla chaetica at 0.190 .26 .

Abdomen with $36 \mathrm{~s}$ :ae on tergite VIII, 51 on sternite VIII.

Genitalia as in Fig. 1 Tergite IX divided into 1 altogether 25 setae. Cerc sule $68 \mu \mathrm{m}$ long $60 \mu \mathrm{n}$

Gonocoxite IX with 23 setae. wo setigerous protrusionswith us $158 \mu \mathrm{m}$. long. Seminal capwide. Notum $101{ }_{\mu} \mathrm{m}$ long

Euryhapsis fusciprot es sp. n.

(Fig. 2).

Type material : Holc type $\sigma$ China, Ningxhia, Mt. Liupan, 7VIII. 1987. X. Wang (XW No. 1245). Paratypes $2 \sigma^{\circ}$, as holor ype (XW, ZMB).

\section{Diagnostic characters}

The species is distinguis hed by having all of front tibia and tarsi blackish bri Jwn. It is separable from the similar $E$. cilium by ha ving setae on wing veins Sc, $M$ and $P c u$ and in oel $! m$, but fewer setae on squama ; and tr ansverse st arnapodeme with longitudial median ridge and slightly convex sides.

\section{Etymology}

From the Latin, fuscus, brown, dark ; pro-, in front, first etc., and pes, foot, referning to the dark front leg.

\section{Description}

Male imago ( $n=3$, except when otherwise stated). Total length $3.95-4.30 \mathrm{~mm}$. Wing length $2.48-2.61 \mathrm{~mm}$. Total length/wing length 1.60-1.68. Wing length/length of profemur 2.34-2.50. Coloration pale brown. Legs stramineous with apices of femora, bases of middle and hind tibia, and all of front tibia and front tarsi blackish brown. Abdomen with anterior dark band on tergites II-VII widest laterally, and tergites VIII-IX dark -medially. Wing with third axillary sclerite dark apically.

Head (Fig. 2A). AR 1.51-1.67. Ultimate flagellomere 699-747 $\mu \mathrm{m}$ long. Temporal setae 18-20(2), including 6-7(2) inner vericals, 6-7 outer verticals, and 6)2) postorbitals. Clypeus with $15-22$ setae. Tentorium 154-184 $\mu \mathrm{m}$ long, 34-38 $\mu \mathrm{m}$ wide. Stipes $146-184 \mu \mathrm{m}$ long, $60 \mu \mathrm{m}$ wide. Palp segments lengths (in $\mu \mathrm{m}$ ) : 41-49, 60-64, 158-164, 173-184, 191-210. Third palpal segment with 2 very long slender sensilla clavata at apex.

Thorax (Fig. 2B). Antepronotum with 2 median and 9-10 lateral antepronotals. Dorsocentrals 38-47, in 1-3 row, prealars 9-10, and supraalar 1. Scutellum with 18-22 setae.

Wing (Fig. 2O). VR 1.25-1.29. Cextension 71-90 ${ }_{\mu} \mathrm{m}$ long. Brachiolum with 5-8 setae, $\mathrm{C}$ extension with 12-22 non marginal setae, $S c$ with 15-21, $R$ with 55-66, $\mathbf{R}_{\mathbf{1}}$ with $64-84, \mathbf{R}_{\mathbf{4}+5}$ with 127-133, $\mathrm{RM}$ with $0-1, \mathbf{M}$ with 3-11, $\mathbf{M}_{1+2}$ with abouth $90-125, \mathbf{M}_{3+4}$ with about $95-120, \mathrm{Cu}$ with $56-63, \mathrm{Cu}_{1}$ with $45-60$, Pcu with 25-33 apically, and An with 57-62 setae. Wing membrane with 2-10 setae in cell $\mathrm{m}$ basally of RM, other cells extensively setose. Squama with 8-12 setae.

Legs. Spur of front tibia $56 \mu \mathrm{m}(1)$ long, spurs of middle tibia 56-64 ${ }_{\mu} \mathrm{m}$ and $53-60 \mu \mathrm{m}$ long, of hind tibia $71 \mu \mathrm{m}(2)$ and $53-60 \mu \mathrm{m}$ long. Width at apex of front tibia 53-56 $\mu \mathrm{m}(2)$, of middle tibia $49-60 \mu \mathrm{m}$, of hind tibia $56-66 \mu \mathrm{m}$. Comb of 6-8 setae, shortest setae 34-49 $\mu_{\mu} \mathrm{m}$ long, longest setae 53-68 ${ }_{\mu} \mathrm{m}$ long. Sensilla chaetica not observed. Lengths (in $\mu \mathrm{m}$ ) and proportions of legs :

\begin{tabular}{|c|c|c|c|c|c|c|c|c|c|c|c|}
\hline & fe & $\mathrm{ti}$ & $\mathbf{L}_{1}$ & $\mathrm{ta}_{2}$ & $t_{3}$ & $\mathrm{ta}_{4}$ & $\mathrm{ta}_{5}$ & LR & BV & sv & $\mathrm{BR}$ \\
\hline$p_{1}$ & $992-1115$ & $1295-1370$ & $1101(1)$ & - & - & - & - & $0.80(1)$ & - & $2.26(1)$ & $2.9(1)$ \\
\hline$p_{2}$ & $992-1119$ & 973-1077 & $482-548$ & $265-293$ & $175-198$ & 104-123 & $76-85$ & $0.49-0.50$ & $3.81-3.95$ & $4.02-4.11$ & $2.8-5.0$ \\
\hline $\mathrm{p}_{3}$ & $1143-1238$ & $1299-1408$ & $803-88$ & $458-496$ & $302-340$ & $170-198$ & $85-95$ & 0.62 & $3.16-3.24$ & $3.02-3.04$ & $3.3-4.7(2)$ \\
\hline
\end{tabular}



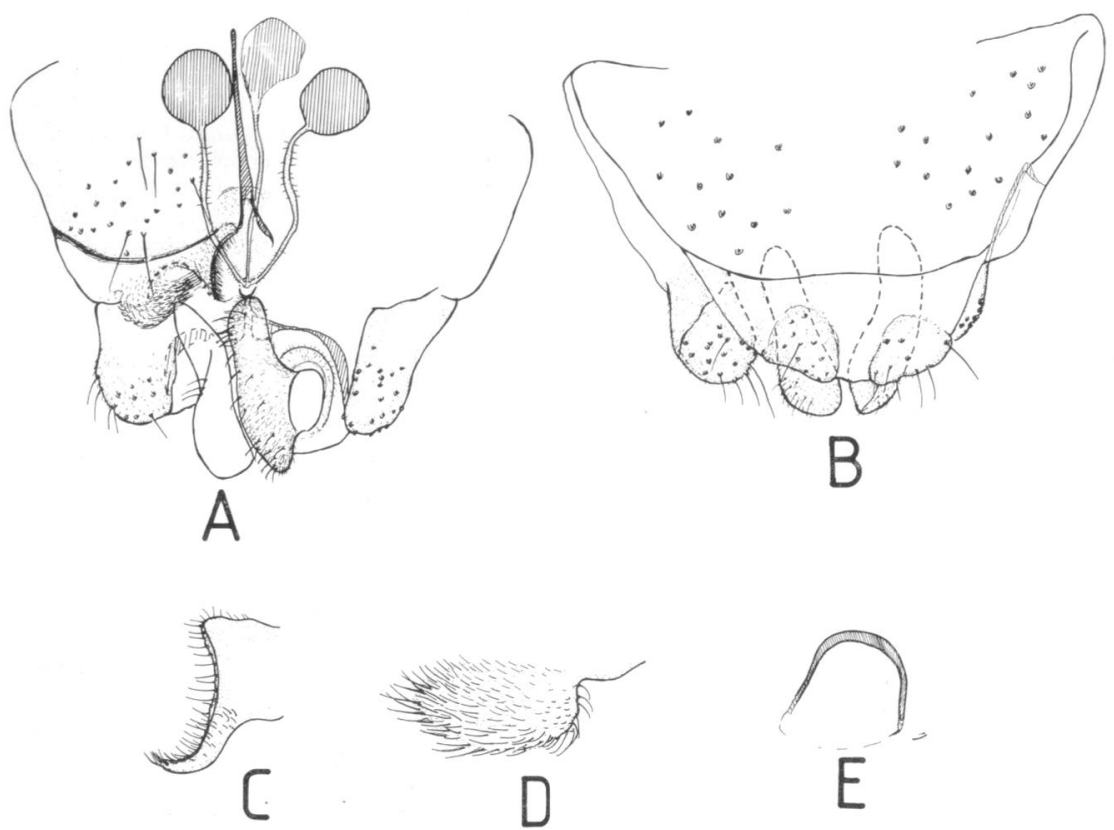

Fig. 1. Euryhapsis cilium Oliver, female genitalia : A. Ventral view ; B. Dorsal view ; C. Dorsomesal lobe ; D. Ventrolateral lobe ; E. Apodeme lobe.

Fig. 1. Euryhapsis cilium Oliver, genitalia femelle : A. Vue ventrale ; B. Vue dorsale ; C. Lobe dorsomésal ; D. Lobe ventrolétéral ; E. Lobe apodème.

Hypopygium (Fig. 2D). Tergite IX with 21-28 setae in two groups, laterosternite IX with 12-16 setae. Phallapodeme $98-105 \mu \mathrm{m}$ long ; transverse sternapodeme rectangular with weakly convex sides, concave apex and longitudial $30-45 \mu \mathrm{m}$ long median ridge. Gonocoxite $225-270 \mu \mathrm{m}$ long ; superior volsella $131-150 \mu \mathrm{m}$ long, $32-36 \mu \mathrm{m}$ wide, with $10-13$ setae, about 10 apical microtrichia, and a few basolateral microtrichia ; inferior volsella $56-60 \mu \mathrm{m}$ long, digitiform, not tapering, with microtrichia and 12-14 setae. (innouylus $98-113 \mu \mathrm{m}$ long from base to apex of apicil lohe, 116-135 $\mu \mathrm{m}$ long from base to apex of subapical lobe, distance from base to furcation $38-41 \mu \mathrm{m}$; with 2 terminal, 2 subterminal lamellate setae, 5-6 additional lateral setae, and microtrichia in basal half of apical lobe. HR 2.31-2.40, HV 3.81-4.05.

\section{Remarks}

The species will key to $E$. cilium in Oliver (1981). It differs in having dark front leg, more numerous setae on the wing but fewer on the squama, transverse sternapodeme with median ridge, and apical lobe of gonostylus with microtrichia. 

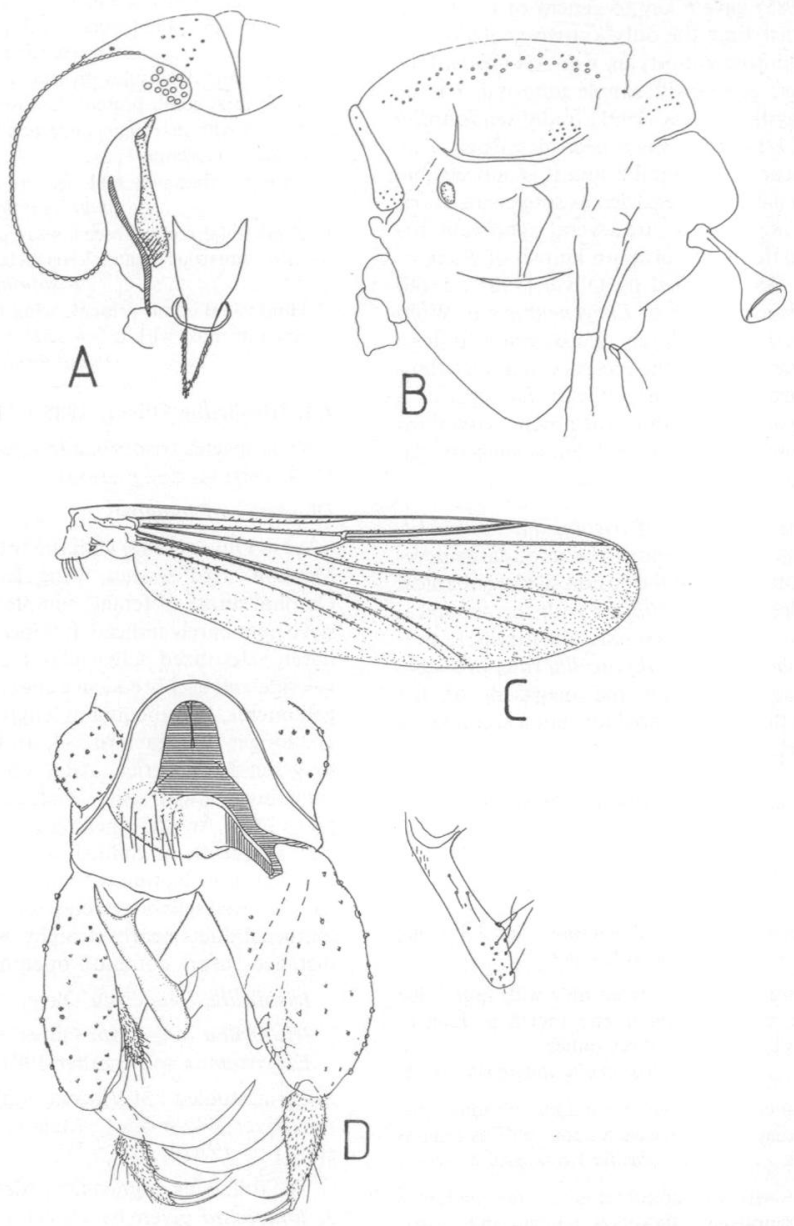

Fig. 2. Euryhapsis fuscipropes sp.n., male imago : A. Head; B. Thorax ; C. Wing; D. Hypopygium with ventral view of superior volsella. Fig. 2. Euryhapsis fuscipropes n.sp., imago mâle : A. Tête ; B. Thorax ; C. Aile ; D. Hypopyge avec vưe ventrale de la volsella supérieure. 


\section{A review of genera near Irisobrillia Oliver}

Oliver (1985) gave a key to genera of the Brillia group. At that time the only known genus of the group with simple gonostylus was Irisobrillia Oliver. Two more genera with simple gonostyli, Tokyobrillia Kobayshi \& Sasa (1991) and Pseudobrillia Niitsuma (1991), have since been described. The three genera are quite similar and it is conceivable that they all should be regarded as subgenera of $\mathrm{Ir}$ sobrillia. However, there are several significant differences and the immatures are known of Pseudobrillia only. As indicated by Oliver (1985: 1106) either Euryhapsis Oliver or Eurycnemus v.d. Wulp appear to be the most closely related genus to these genera. However, while the presence of a third thinwalled seminal capsule in Tokyobrillia suggests a relationship with Euryhapsis, the absence of a third capsule in Irisobrillia and Pseudobrillia suggests that these genera are closer to Brillia.

The simple gonostylus of Irisobrillia, Tokyobrillia and Pseudobrillia appears to be secondarily developed for instance from the fusion of the subapical and apical lobes of Euryhapsis with the subapical lobe forming the main element. The megaseta present in Irisobrillia and Tokyobrillia thus probably is not homologous with the megaseta of the gonostyli of the other orthoclads, but a secondarily thickened seta.

Key to male imagines of genera near Irisobrillia

1. Gonostylus without macroseta or other strong setae, subcosta bare ; Japan and China

............. Pseudobrillia komorii Niitsuma

Gonostylus with long apical macroseta and $2-3$ strong preapical setae, subcosta with setae $\ldots \ldots \ldots \ldots 2$

2. Hind tibial comb absent, front tibia with spur, wing cuneiform, megaseta about one fourth as long as gonostylus; Venezuela, West Indies

Irisobrilia longicosta Oliver

Hind tibial comb present, front tibia without spur, wing not cuneiform, megaseta about half as long as gonostylus .....Tokyobrillia Kobayashi \& Sasa 3

3. Gonostylus with 3 preapical setae ; thorax, abdomen and legs completely pale yellow; Japan and China

.......... T. tamamegaseta Kobayashi \& Sasa

Gonostylus with 2 preapical setae, dark markings on thorax, abdomen banded, legs slightly ringed ; Tanzania $. . . \ldots \ldots \ldots \ldots \ldots \ldots . T$. anderseni sp.n.
Key to female imagines of genera near Irisobrillia

1. Third thin-walled seminal capsule present, front tibia without spur, hind tibial comb present .......... ............ Tokyobrillia Kobayshi \& Sasa 2 Two seminal capsules present, front tibia with spur, hind tibial comb present or absent ......... 3

2. Thorax with markings, abdomen banded, legs slightly ringed; Tanzania .........T. anderseni sp.n. Thorax, abdomen and legs unmarked, Japan and China ...... T. tamamegaseta Kobayashi \& Sasa

3. Hind tibial comb absent, wing cuneiform, subcosta with numerous setae; Venezuela and West Indies.

Irisobrillia longicosta Oliver

Hind tibial comb present, wing not cuneiform, subcosta at most with a few setae ; Japan and China . Pselidobrillia komorii Nitsuma

\subsection{Irisobrillia Oliver, $1985: 1105$}

Type species Irisobrillia longicosta Oliver, 1985 : 1109 (original designation)

\section{Diagnosis of imagines}

As in Oliver (1985) with the following additions : Medium sized species, wing length $1.0-2.8 \mathrm{~mm}$. Coronal suture of female complete. Tentorium with sieve pore barely indicated. Stipes with median plate barely sclerotized. Cibarial pump with slightly convex side and evenly concave apex. Female with 5 flagellomeres, Ist subequal in length to 5 th and about $1 / 3$ longer than each of $2-4$, all flagellomeres with long sensilla chaetica. All veins except $\mathrm{R}_{2+3}$ and sometimes $\mathbf{M}$ with setae. Postcubitus ending far distal to FCu. An not reaching FCu. Female genitalia with tergite IX undivided, but with setae arranged into 2 groups. Notum with rami continuing in parallel. Two well sclerotized bare seminal capsules. Spermathecal ducts nearly straight, widened for a long distance before common opening.

Irisobrillia longicosta Oliver

Irisobrillia longicosta Oliver 1985: 1109

Eurycnemus sp., Sather 1981:2

Material studied : St.Vincınt, Majorca Estate, Yambou River, 442 m a.s.l., Malaise trap, A.D. Harrison, 1 (ZMB).

The following augments the description of female I. longicosta given by Oliver (1985) and Sæther (1981).

Female imago $(\mathrm{n}=1)$

Total length $1.47 \mathrm{~mm}$. Wing length $1.01 \mathrm{~mm}$. Wing length/length of profernur 2.28 . 
Head (Sather 1981 fig. 1A). Temporal setae 12, including 6 inner verticals, 3 outer verticals and 3 postorbitals. Clypeus with 14 setae. Tentorium 90 $\mu \mathrm{m}$ long, $11 \mu \mathrm{m}$ wide. Stipes $94 \mu \mathrm{m}$ long, $15 \mu \mathrm{m}$ wide. Palp segments length (in $\mu \mathrm{m}$ ) : 19, 23, 64, 64, 75.

Thorax (Sæther 1981 fig. 1B). Antepronotum with 6 dorsolateral setae and 3 ventral setae. Dorsocentrals 19 , prealars 4 , supraalar apparently absent (thorax broken). Scutellum with 10 setae.

Wing (Sæther 1981 fig. 1C). VR 1.75. C extension $101 \mu \mathrm{m}$ long. Brachiolum with 2 setae, $C$ extension with 33 non-marginal setae, $S c$ with $21, R$ with $26, R_{1}$, with $20, R_{4+5}$ with $35, R M$ with $2, M$ with $1, \mathrm{M}_{1+2} 27, \mathrm{Cu}$ with $37, \mathrm{Cu}_{1}$ with 14 , Pcu with 30 , and An with 14 setae. Wing membrane with 17 setae in cell $\mathrm{m}$ basally of RM, other cells extensively setose. Squamal setae not observed.

Legs. Spur of front tibia $23 \mu \mathrm{m}$ long, spurs of hind tibia $34 \mu \mathrm{m}$ and $30 \mu \mathrm{m}$ long. Width at apex of front tibia $26 \mu \mathrm{m}$, of hind tibia $30 \mu \mathrm{m}$ long. Comb of hind tibia absent. Front femur $444 \mu \mathrm{m}$ long, hind femur $477 \mu \mathrm{m}$ long, front tibia $482 \mu \mathrm{m}$ long, hind tibia $539 \mu \mathrm{m}$ long. Tarsi lost.

Abdomen. Tergite VIII with 16 setae. Sternite VIII with 42 setae.

Genitalia (Sather 1981 fig. 1D). Gonocoxite with 7 setae. Tergite IX with 16 setae. Cercus $56 \mu \mathrm{m}$ long. Seminal capsules $53 \mu \mathrm{m}$ long, $39 \mu \mathrm{m}$ wide ; no third transparent seminal capsule observed on this well cleared specimen. Notum $71 \mu \mathrm{m}$ long.

\section{Remarks}

Oliver (1985: 1109) regarded the female from St.Vincent as conspecific with the males from Venezuela. Although this seems highly likely it should be mentioned that the female is considerably smaller and that setae on the squama not were observed in the female. However, since the squama is not complete, the thorax broken, and the tarsi lost, a final decision about conspecificity can only be made on additional material.

\subsection{The genus Tokyobrillia Kobayashi \& Sasa}

Tokyobrillia Kobayashi \& Sasa, 1991 : 73

Orthocladiini gen. sp., Kobayashi 1991: 80

Type species Tokyobrillia tamamegaseta Kobayashi \& Sasa, 1991: 74 (original designation).

\section{Diagnosis of imagines}

Medium sized species, wing length 1.4-2.0 mm. Coloration pale to yellowish brown, with or without dark markings or bands on thorax, abdomen and legs.

Eyes with long and rectangular dorsomedial extension, bare but with microtrichia present medial to ommatidia on inner margin and on apex of dorsomedial extension. Coronal suture of female complete, reduced or absent. Tentorium with sieve pore barely indicated, usually with a few basal microtrichia, widest near base in female. Stipes with median plate barely sclerotized. Cibarial pump with slightly convex side and evenly concave apex. Temporal setae extending from behind and above eyes to near coronal suture, with inner verticals relatively numerous. Clypeus with setae on raised area. Maxillary palp 5-segmented, 3rd segment longer than 4th and subequal in length to 5 th ; sensilla clavata present on lateral and median apex of $3 \mathrm{rd}$, on lateral apex of 4 thi.

Antennal ratio of male higher than 1 ; groove starts on flagellomeres 3 or 4 : very long sensilla chaetica present at least on flagellomeres 2 and 3 and possibly always on 2.5 and ultimate, no strong apical seta. Female with 5 flagellomeres, lst subequal in length to 5 th and about $1 / 3$ longer than each of $2-4$, all flagellomeres with long sensilla chaetica.

Antepronotal lobes, widely separated medially, with dorsal and ventral setae and additional dorsolateral setae in female. Scutal projection rectangular, rising above antepronotum. Dorsocentrals unito multiserial extending to near antepronotum, acrostichals absent, prealars uni- biserial, supraalars absent, anepisternals and preepisternals absent. Scutellum with setae in uni- biserial transverse row.

Wing with weakly developed, not projecting anal lobe. Wing membrane with setae in most cells, with coarse punctation. All veins except $\mathbf{R}_{2+3}$ with setae. Costa strongly extended beyond $R_{4+5}$ and ending near wing tip ; $R$ short ; $\mathbf{R}_{\mathbf{2}+3}$ running and ending close to $R_{1} ; R_{4+5}$ ending distal to end of $M_{3+4}$; $R M$ long, oblique, and running nearly in direction of $\mathrm{R}$; $\mathrm{Cu}_{1}$ slightly curved ; postcubitus ending far distal to $\mathrm{FCu}$, An not reaching FCu. Squama with few setae.

Front tibia without spur, mid tibia with 2 spurs of equal length ; hind tikia with 2 spurs of subequal 
length, with oblique comb of few setae (5-10). Tarsi long bearded (but setae usually fallen off), some straight setae of 2 lengths, some curved and apparently narrowly scale-like. Pseudospurs absent, sensilla chaetica not observed. Pulvilli vestigial, claws small, normal.

Abdomen long and narrow with at least segment VII longer than wide. Tergites with multiple row of lateral setae and scattered, few to numerous setae over anterior $2 / 3$ of tergites. Sternites with lateral row of setae and with anteriomedian concentration of median setae.

Male hypopygium with segment IX narrow, tergite IX with a group of setae on each side of midline on a more or less pronounced protrusion, anal point absent. Sternapodeme with straight or slightly concave sides, transverse sternapodeme nearly straight with oral projections directed mostly laterally. Phallapodeme well developed, with aedaegal lobe small. Virga absent. Gonocoxite parallel-sided and elongate ; superior volsella elongate and narrow, with weak setae and a strong microtrichia in basal third or less.

Female genitalia with tergite IX divided in 2 set 1 gerous protrusions. Gonocoxite IX well-developed, setiferous. Gonocoxapodeme VIII evenly curved. Gonapophysis VIII divided into large ventrolateral lobe with long apical microtrichia and well developed dorsomesal lobe. Notum relatively long with rami continuing in parallel. Apodeme lobe well developed. Postgenital plate large, triangular with rounded apex. Cerci well developed. Two well sclerotized and one thin-walled seminal capsule void of microtrichia. Spermathecal ducts of sclerotized capsules nearly straight, widened before partly common opening.

Pupa and larva. Unknown.

\section{Tokyobrillia anderseni sp.n.}

(Figs. 3, 4).

Type material : Holotype : $\sigma:$ Tanzania, Tanga region, West Usumbara, Mts Mazumbai, Kaputo River, 4-6. XI.1990, ZMB Expedition (ZMB Type No. 149). Paratypes: $36 \%, 52 \%$, as holotype except 28.X-13.XII. 1990 (ZMB, TK, XW, CNC, ZSM).

Diagnosis characters : See keys.

\section{Etymology}

Named in honour of $\mathrm{Mr}$. Trond Andersen, Museum of Zoology, Bergen, the leader of the expedition to Tanzania where these specimen were collected.

\section{Description}

Male imago $(n=10-12$, except when otherwise stated).

Total lenght $2.69-3.63,3.19 \mathrm{~mm}$. Wing length 1.45-1.93,1.71 mm. Total length/wing length 1.78-1.89,1.85. Wing length/length of profemur $1.76-1.87,1.82$. Coloration pale brownish yellow with dark brown vittae, anterior and median anepisternum II, part of episternum and postnotum. Legs stramineous with front and usually mid trochanter dark, profemur darker in basal half, mid femur slightly darkened in basal half. Wing with brownish black spot apically in third axillary sclerite. Abdomen (Fig. 3E) with dark band in oral half of tergites II-VI, band often indicated also on I and VIII.

Head (Fig. 3A). AR 1.39-1.76,1.55. Ultimate flagellomere 539-709,631 $\mu \mathrm{m}$ long. Temporal setae $10-20,15$; including $5-12,9$ inner verticals ; $2-4,3$ outer verticals ; and $2-4,3$ postorbitals. Clypeus with 10-14,12 setae. Tentorium 131-169,150 $\mu \mathrm{m}$ long ; 21-30,25 $\mu \mathrm{m}$ wide. Stipes 118-173,161 $\mu \mathrm{m}$ long ; 19-38,25 $\mu \mathrm{m}$ wide. Palp segments lengths (in $\mu \mathrm{m}$ ) : $34-39,36$; 60-79,70; 150-214,191(6); 135-146, 41(4) ; 131-199,171(4). Third palpal segment with 2 lateral and 1 median sensilla clavata, fourth with 1 lateral sensilla ciavat $u m$.

Thorax (Fig. 3B). Antepronotum with 4-7,5 dorsomedian and 2-5,4 veritrolateral setae. Dorsocentrals $24-53,38$ starting close to antepronotum ; prealars 4-9,7; supraalars absent. Scutellum with $12-19,15$.

Wing (Fig. 3c). VR 1.54-1.75, 1.63. C extension $71-113,95 \mu \mathrm{m}$ long. Brachiolum with $2-4,3$ setae ; $C$ extension with 18-40.31 non-marginal setae ; Sc with $28-53,39$; $R$ with $45-78,64$; $R_{1}$ with $40-78,58$; $\mathrm{R}_{4+5}$ with 44-118,88; $\mathrm{RM}$ with 4-15,9; $\mathrm{M}$ with $1-6,3 ; M_{1+2}$ with abcut $80-120,95 ; M_{3+4}$ with 44-70,56; $\mathrm{Cu}$ with $32-60,51 ; \mathrm{Cu}_{1}$ with $24-40,33$; Pcu with 47-95,72; and An with 26-56,38 setae. Wing membrane with $18,-48,35$ setae in cell $m$ basally of RM, other cells extensively setose. Squama with 3-6,4 setae. 

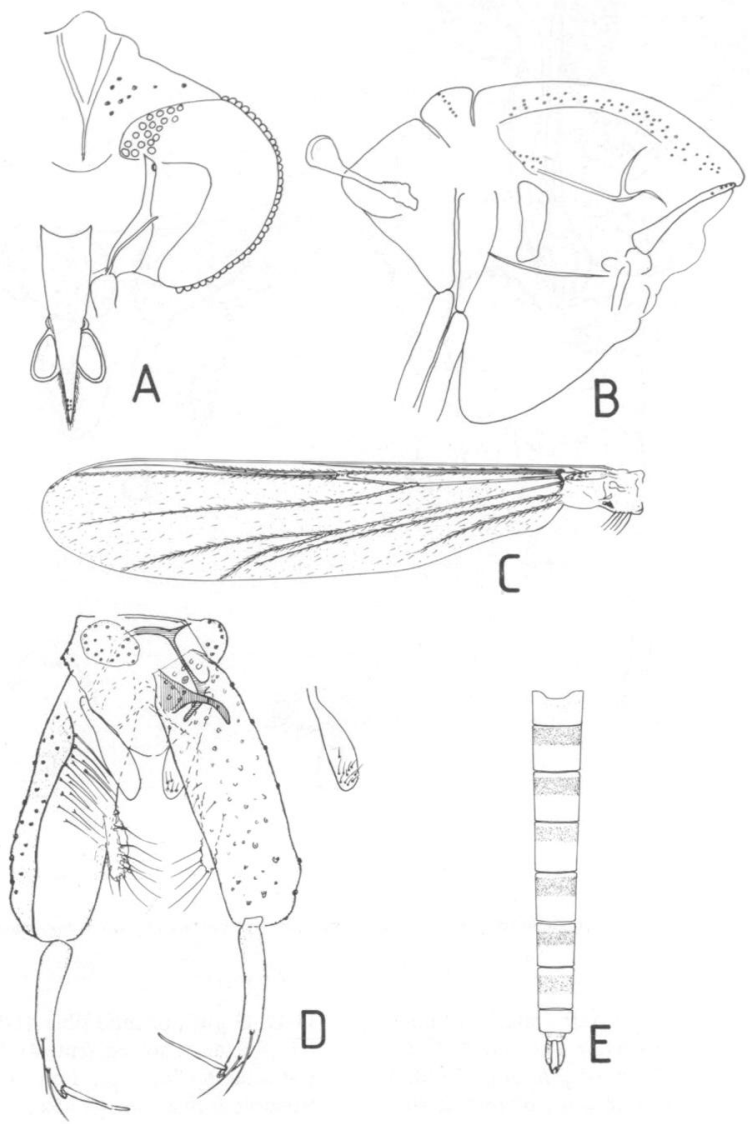

Fig. 3. Tokyobrillia anderseni sp.n., male imago : A. Head ; B. Thorax ; C. Wing ; D. Hypopygium with ventral view of superior volsella ; E. Abdomen.

Fig. 3. Tokyobrillia anderseni n.sp., imago mâle : A. Tête ; B. Thorax ; C. Aile ; D. Hopopyge avec vue ventrale de la volsella supérieure; E. Abdomen. 

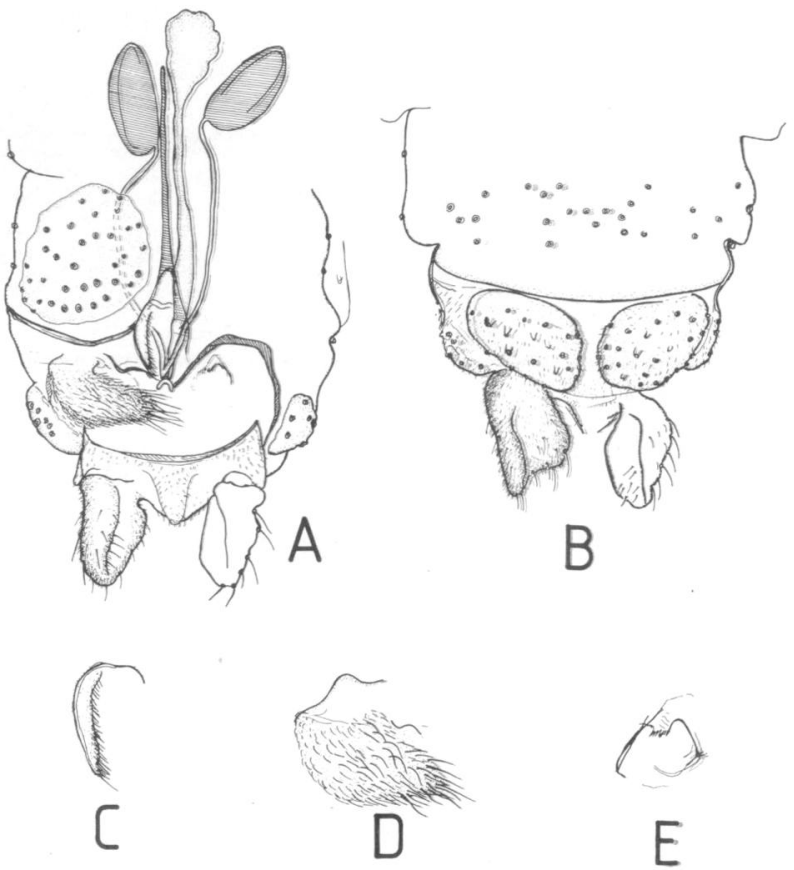

Fig. 4. Tokyobrillia anderseni sp.n., female genitalia : A. Ventral view ; B. Dorsal view ; C. Dorsomesal bebe ; D. Ventrolateral lobe : E. Apodeme lobe.

Fig. 4. Tokyobrillia anderseni n.sp., genitalia femelle : A. Vue ventrale ; B. Vue dorsale ; C. Lobedorsomesal ; D. Lobe ventrolatéral ; E. Lobe apodème.

Legs. Front tibia without spur ; spurs of middle tibia 53-71,62 $\mu \mathrm{m}$ and 49-64,58 $\mu \mathrm{m}$ long ; of hind tibia 71-90,81 $\mu \mathrm{m}$ and 53-79,67 $\mu \mathrm{m}$ long. Width at apex of front tibia $30-43,38 \mu \mathrm{m}$; of middle tibia
$38-49,43 \mu \mathrm{m}$; of hind tibia $41-54,48 \mu \mathrm{m}$. Comb of $7-10,8$ setae ; shortest setae $41-53,44 \mu \mathrm{m}$ long ; longest setae 60-98,77 $\mu \mathrm{m}$ long. Lengths (in $\mu \mathrm{m}$ ) and proportions of legs $\left(n=3=5\right.$ on $\left.\operatorname{ta}_{1-5}, \mathrm{LR}, \mathrm{BV}, \mathrm{SV}\right)$ :

\begin{tabular}{|c|c|c|c|c|c|c|c|c|c|c|c|}
\hline & $\mathrm{fe}$ & $\mathrm{ti}$ & $\mathbf{t a}_{1}$ & $\mathrm{ta}_{2}$ & $\mathrm{ta}_{3}$ & $\mathrm{ta}_{4}$ & $\mathrm{ta}_{5}$ & LR & BV & SV & $\mathbf{B R}(\mathbf{n}=0-2)$ \\
\hline$p_{1}$ & $775-1068,944$ & $926-1304,1139$ & $945-1044$ & $473-548$ & $312-383$ & $208-246$ & $85-89$ & $0.85-0.86$ & $2.55-2.72$ & $2.10-2.15$ & - \\
\hline$p_{2}$ & $737-1025,899$ & $671.917,895$ & $520-662,613$ & $260-331,309$ & $165-213,199$ & $104-128,120$ & $57-76,69$ & $0.69-0.73,0.71$ & $3.36-3.61,3.48$ & $2.83-3.25,3.00$ & $4.2-5.0$ \\
\hline $\mathbf{p}_{3}$ & $765-1049,938$ & $832-1139,1004$ & $633-898,796$ & $350-491,437$ & $241-350,304$ & $132-194,169$ & $66-85,79$ & $0.76-0.81,0.79$ & $2.75-2.83,2.78$ & $2.34-2.52,2.45$ & 5.4 \\
\hline
\end{tabular}


Hypopygium (Fig. 3D). Tergite IX with $22-40,29$ setae in two groups laterosternite IX with $2-5,3$ setae. Phallapodeme $75-94,81 \mu \mathrm{m}$ long ; transverse sternapodeme 34-64,51 $\mu \mathrm{m}$ long. Gonocoxite 218-278,256 $\mu \mathrm{m}$ long ; superior volsella $75-113,100$ $\mu \mathrm{m}$ long ; 23-34,28 $\mu \mathrm{m}$ wide ; with $11-19,13$ weak setae or strong microtrichia ventrally ; inferior volsella 53-90,68 $\mu \mathrm{m}$ long, with $8-16,13$ setae. Gonostylus $131-169,153 \mu \mathrm{m}$ long, megaseta 60-79,71 $\mu \mathrm{m}$ long ; basal preapical seta 56-71,62 $\mu \mathrm{m}$ long ; apical preapical seta $38-60,47 \mu \mathrm{m}$ long. HR 1.63-1.72,1.67 ; HV 1.94-2.26,2.10.

Female imago $(\mathrm{n}=10$, except when otherwise stated)

Total length $2.12-3.59,2.66 \mathrm{~mm}$. Wing length $1.58-2.09,1.81 \mathrm{~mm}$. Total length/wing length. Wing length/length of profemur 1.82-1.93,1.86. Coloration as in male.

Head. AR 0.29-0.35,0.32(6). Lengths (in $\mu \mathrm{m}$ ) of flagellomere $(\mathrm{n}=6)$ : $98-135,113 ; 68-101,85$; 75-101,90;45-77,66; 94-120,109. Temporal setae 13-23,17 ; including 8-18,11 inner verticals ; $2-4,3$ outer verticals ; and 2-3,3 postorbitals. Tentorium 120-146,130 $\mu \mathrm{m}$ long ; 19-32,22 $\mu \mathrm{m}$ wide. Stipes 146-199,164 $\mu \mathrm{m}$ long ; 19-34,26 $\mu \mathrm{m}$ wide. Palp segments lengths (in $\mu \mathrm{m}$ ): $30-45,36$; 56-90,69; $169-199,183(6) ; 124-139,131(6) ; 184-225,212(6)$.
Sensilla clavata as in male. Coronal suture incomplete $0-49,31 \mu \mathrm{m}$ long ; when not sclerotized indicated by shadow.

Thorax. Antepronotum with 8-13,10 dorsomedian and dorsolateral setae, and 2-6,4 ventral setae. Dorsocentrals $38-60,49$; prealars $10-14,11$; supraalars absent. Scutellum with 19-24,22 setae.

Wing. VR 1.63-1.77,1.68. C extension 94-135,116 $\mu \mathrm{m}$ long. Brachiolum with 3-6,4 setae ; C extension with 39-56,47 non-marginal setae; Sc with 43-84,62 ; R with 59-95,75; $\mathrm{R}_{1}$ with $61-96,75$; $\mathrm{R}_{4+5}$ with about $105-185,135$; $\mathrm{RM}$ with $10-26,18$; $\mathrm{M}$ with $5-17,12 ; \mathrm{M}_{1+2}$ with about $90-165,125$; $\mathrm{M}_{3+4}$ with 49-100,74; $\mathrm{Cu}$ with 49-80,65; $\mathrm{Cu}_{1}$ with 28-60,42 ; Pcu with about 60-160,100 ; and An with $30-53,45$ setae. Wing membrane with $48-117,78$ setae in cell $\mathrm{m}$ basally of RM ; other cells extensively setose. Squama with 4-9,6 setae.

Legs. Front tibia without spur ; spurs of middle tibia 56-69,61 $\mu \mathrm{m}$ and 53-64,56 $\mu \mathrm{m}$ long ; of hind tibia $68-86,76 \mu \mathrm{m}$ and $53-71,63 \mu \mathrm{m}$ long. Width at apex of front tibia $36-45,40 \mu \mathrm{m}$; of middle tibia $39-53,45 \mu \mathrm{m}$; of hind tibia $41-51 \mu \mathrm{m}$. Comb of 5-9,8 setae ; shortest seta $34-53,43 \mu \mathrm{m}$ long ; longest seta $53-83,75 \mu \mathrm{m}$ long. Lengths (in $\mu \mathrm{m}$ ) and proportions of legs ( $n=2-3$ on tarsi and ratios of mid and hind legs) :

\begin{tabular}{ccccccccccc}
\hline & $\mathrm{fe}$ & $\mathrm{ti}$ & $\mathrm{ta}_{1}$ & $\mathrm{ta}_{2}$ & $\mathrm{ta}_{3}$ & $\mathrm{ta}_{4}$ & $\mathrm{ta}_{5}$ & $\mathrm{LR}$ & $\mathrm{BV}$ & $\mathrm{SV}$ \\
\hline $\mathrm{p}_{1}$ & $832-1153,972$ & $964-1342,1163$ & - & - & - & - & - & - & - & - \\
$\mathrm{p}_{2}$ & $780-1058,909$ & $709-964,829$ & $520-619$ & $236-288$ & $161-189$ & $95-113$ & $57-66$ & $0.67-0.71$ & $3.71-3.94$ & $2.94-3.15$ \\
$\mathrm{p}_{3}$ & $803-1077,935$ & $756-1134,978$ & $671-794$ & $350-444$ & $246-302$ & $137-170$ & $57-76$ & $0.75-0.77$ & $2.44-2.85$ & $2.56-2.58$ \\
\hline
\end{tabular}

Abdomen. Number of setae on tergites I-VIII as : $36-56,47$; 47-78,64 ; 55-110,70 ; 65-120,81 ; $60-117,82 ; 49-97,67 ; 40-85,50 ; 20-39,27$. Number of setae on sternites I-VIII as : $0-2,0 ; 13-66,28$; $26-75,54$; 45-103,79 ; 60-135,93 ; 63-128,97 ; $56-110,82 ; 72-132,105$.

Genitalia (Fig. 4). Gonocoxite with 10-22,16 setae. Tergite IX barely to strongly divided into two setigerous protrusions with altogether $34-60,47$ setae. Cercus 71-114,96 $\mu \mathrm{m}$ long. Well sclerotized seminal capsules $60-83,79 \mu \mathrm{m}$ long ; $41-53,47 \mu \mathrm{m}$ wide ; thin-walled capsule $38-75,56 \mu \mathrm{m}$ long ; $36-41,36$ $\mu$ mwide. Notum 98-120,104 $\mu \mathrm{m}$ long.

\section{Remarks}

The fragile nature of Tokyobrillia adults is exemplified by this collection from Malaise traps and sweep nets a along a stream in the West Usumbara Mts in Tanzania. None of the 52 females collected had retained their front tarsi and only 2 specimens had middle and hind tarsi. The bristle ratio probably is high on all legs, but the longer setae are few in number and fall off. The bristle ratio of the middle and hind leg was measurable in one male only out of 37.

$T$. anderseni is very similar to $T$. tamamegaseta from Japan and China, but easily distinguishable by the color pattern. 
Tokyobrillia tamamegaseta (Kobayashi \& Sasa) (Fig. 5)

Tokyobrillia tamamegaseta Kobayashi \& Sasa 1991 : 74. Orthocladiini gen.sp. Kobayashi $1991: 80$.
Material studied : Japan, Kawasaki, Kama-Ku, Masugata ; near Tama River, light trap, $2 \sigma^{\circ}, 2$, 22.VI 1990 , 7.VI. 1991, T. Kobayashi (TK). China, Hainan, Bananghing, $1 \%$ 10.V.1998, X. Wang (XW).
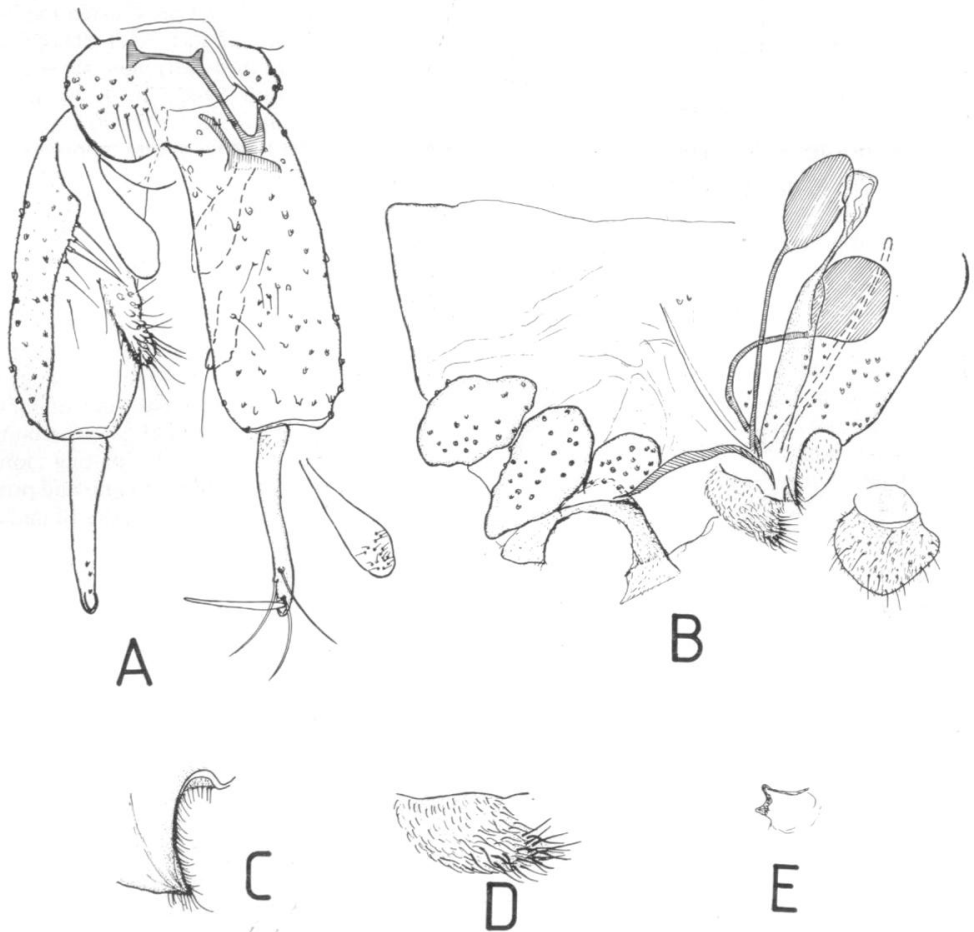

Fig. 5. Tokyobrillia tamamegaseta Kobayashi \& Sasa : A. Male Hypopygium with ventral view of superior volsella ; B-E. Female genitalia ; ventrolateral view (B, cerci lost, with cercus of different specimen in lateral view) ; dorsomesal lobe (C); ventrolateral lobe (D) ; and apodeme lobe (E).

Fig. 5. Tokyobrillia tamamegaseta Kobayashi \& Sasa : A. Hypopyge mâle avec vue ventrale de la volsella supérieure ; B-E. Genitalia femelle; vue ventrolatérale (B, cerques perdus, avec cerque d'un spécimen différent en vue latérale) ; lobe dorsomésal (C); lobe ventrolatéral (D) ; et lobe apodème (E). 
The following augments the description of $T$. tamamegaseta by Kobayashi \& Sasa (1991) and Kobayashi (1991).

Male imago ( $n=2-3$ except when otherwise stated).

Third axillary sclerite with apical black spot. All measurements and counts within the variation of $T$. anderseni sp.n. with the following exceptions :

Wing length $1.34-1.66 \mathrm{~mm}$. Wing length/length of profemur 1.68-1.88.

Head. AR 1.18-1.48. Ultimate flagellomere 473-567 $\mu \mathrm{m}$ long. Sensilla chaetica present on flagellomeres 2-5 and ultimate.

Thorax. Dorsocentrals 21-37. Scutellum with 10-17 setae.

Wing. Subcosta with 52-56 setae, R with 40-54, $R_{1}$ 40-54, $R_{1}$ with 31-55, and $M$ with 7-9 setae. Squama with $4-10$ setae.

Legs. Comb of 5-6 setae. Bristle ration of middle leg 7.4(1), of hind leg 8.0(1).

Hypopygium (Fig. 5A). Gonocoxite 206-251 $\mu \mathrm{m}$ long, superior volsella with 15-21 weak setae ventrally. Gonostylus $113-124 \mu \mathrm{m}$ long, basal preapical seta 56-60 $\mu \mathrm{m}$ long, median $45 \mu \mathrm{m}$ long, apical preapical seta $34-38 \mu \mathrm{m}$ long.

Female imago $(n=1-2)$

All measurements and counts within the variation of $T$. anderseni with the following exceptions :

Wing length $1.46-1.57 \mathrm{~mm}$. Wing length/length of profemur 1.58-1.70.

Head. Flagellomere $471-79 \mu \mathrm{m}$ long, flagellomere $5113-135 \mu \mathrm{m}$ long. Temporals $12-13$, including 6-7 inner verticals. Three ultimate palpal segments lengths (in $\mu \mathrm{m}$ ) as : 39-146, 101-116, 150-169.

Thorax. Dorsocentrals 32, prealars 8. Scutellum with 15-17 setae.

Abdomen. Sternite VIII with 58 setae and probably fewer setae than in $T$. andersen $i$ also on other sternites.

Genitalia (Fig. 5B-E). Notum $75 \mu \mathrm{m}$ long.

\section{Remarks}

The smaller measurements belong to the specimen from China, which also has lost the megaseta. The antennal ratio is lower (1.18), there are only few (4) setae on the squama, and the bristle ratios are very high. However, the bristle ratios could not be measured on the Japanese specimens. None of the observed dissimilarities, however, are significant enough to warrant separate specific status.

Both this species and the following species are found only from the southern Oriental parts of China in addition to Japan, and suggest that the whole group of genera near Irisosobrillia is a Gondwanian element.

\subsection{The genus Pseudobrillia Niitsuma}

Pseudobrillia Niitsuma, 1991: 707

Type species Pseudobrillia komorii Niitsuma, 1991 : 709 (original designation).

\section{Diagnosis}

As in Niitsuma (1991) and essentially as in Tokyobrillia with the following exceptions and additions : Antepronotum with dorsal and ventral setae and additional dorsolateral setae both in male and female. One or two supraalars present. Subcosta bare in male. Squama with about 13-27 setae. Inferior volsella fused with gonocoxite, vestigial.

\section{Pseudobrillia komorii Niitsuma}

(Fig. 6)

\section{Pseudobrillia komorii Niitsuma 1991 : 709}

Material studied : China, Hainan, Banvanghing, 1 o 10.V.1988, X. Wang (XW).

The following augments the description of $P$. komorii by Niitsuma (1991).

Male imago $(n=1)$

Wing length about $1.6 \mathrm{~mm}$ (2.1-3.2. in Niitsuma). Wing length/length of profemur about 1.7 in Chinese specimen, about 2.5-2.7 in Niitsuma. Thorax apparently without markings in Chinese specimen.

Thorax. Supraalars 2 ( 1 in Niitsuma). Scutellum with 18 setae (22-49 in Niitsuma).

Wing. Subcosta bare, $R$ with 70 setae, $R_{1}$ with about $50, R_{4+5}$ with about $80, R M$ with $4, M$ with 21 , and $\mathrm{Cu}$ with about 50 setae ; setae on other veins not countable on damaged wing.

\section{Remarks}

The Chinese specimen may show up not to be conspecific with the Japanese. It apparently is more pale, has shorter wing, and 2 supraalars. However, the specimen is damaged and several details obscured. Most measurements fall at the lower end of the variation within $P$, komorii. 

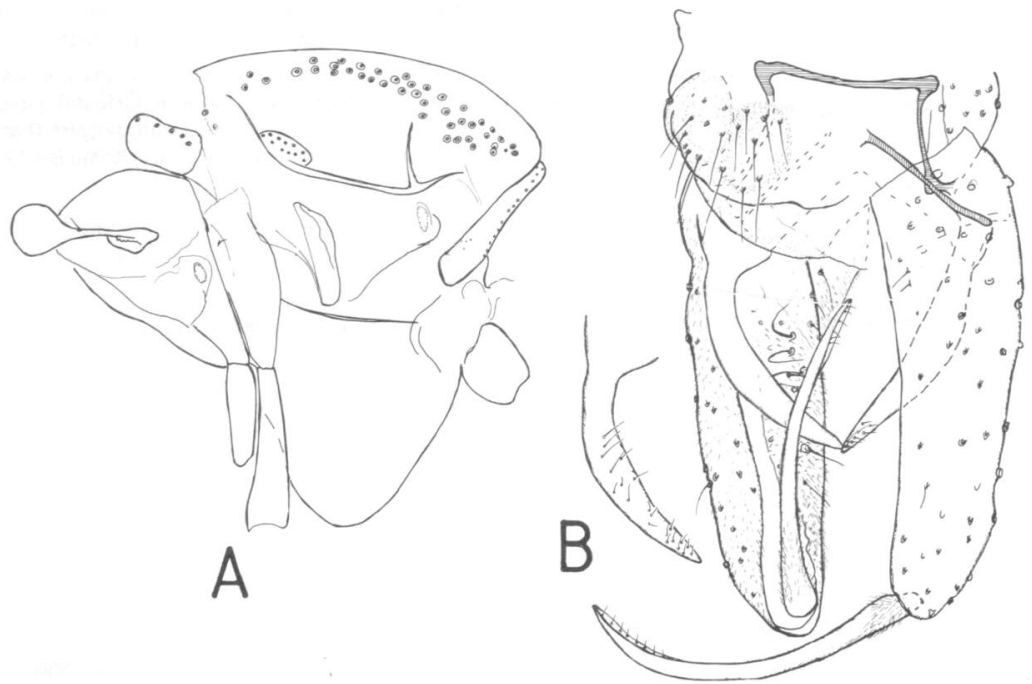

Fig. 6. Pseudobrillia komorii Niitsuma, male imago from China : A. Thorax; B. Hypopyginan.

Fig. 6. Pseudobrillia komorii Niitsuma, imago mâle de Chine : A. Thorax; B. Hypopyge.

\section{Acknowledgements}

We are grateful to Dr. T. Kobayashi, Kawasaki, Japan for the loan of material of $T$. tamamegaseta. Financial support for the junior author was provided by a visiting senior research fellowship from the Council for international cooperation and developmental studies at the University of Bergen, and by a stipend from. the Norwegian Research Council. The manuscript was typed by Annelise Bjornas.

\section{References}

Kobayashi T. 1991. - Chironomids of the Tama Hills (Diptera, Nematocara) (in Japanese) Rep. Natur. Envir. Invest. Kanasaki $2: 7-84$.

Kobayashi T.\& Sasa M. 1991. - Description of two new species of the chironomid mids collected fron the Tama River, Tokyo. (Daptera, Chironoridax). Jpn. J. Sanit. Zool. 42 : $71-75$.

Nusuma H. 1994. - A new genus and species of the primitive Orthocladiinae (Diptera, Chironomidae) from Japan. Jpn. J. Ent. 59 : 707-716
Oliver D.R. 1981. - Description of Euryhapsis new genus including three new species (Diptera, Chirononidae). Can. Ent. 113: $711-822$.

Oliver D.R. 1982. - Xylotopus, a new genus of Orthocladiinae (Diptera, Chironomidae). Can. Ent. 114: 167-168.

Oliver D.R. 1985. - Review of Xylotopus Oliver and description of Irisobrillik n.gen. (Diptera, Chironomidae), Can. Ent. 117 : $1093-1110$.

Sæther O.A. 1969. - Some Nearctic Podonominae, Diamesinae and Orthocladiinae (Diptera : Chironomidae). Bwll. Fish. Res. Bd Can, : 107,154 pp.

Srther O.A. 1977, - Female genitalia in Chironomidae and other Nematocera : morphology, phylogenies, keys. Bull. Fist. Res. Bd Can : 197, 209 pp.

Sæther O.A. 1979. - Hierarchy of the Chironomidae with special emphasis on the female genitalia (Diptera). Ent. scand.r. Suppi. $10: 11.26$.

Sxther O.A. 1980. - Glassary of Chironomid morphology terminology (Diptera : Chironomidae). Ent. scand., Suppl. 14, 51 pp. 
Sather O.A. 1981. - Orthocladiinae (Diptera : Chironomidae) from the British West Indies, with description of Antillocladius n.gen., Lipurometriocnemus, n.gen., Compterosmittia n.gen, and Diplosmittia n.gen. Ent, scand., Suppl. 16, 46 pp.

Sxther O.A. 1982. - Orthocladiinae (Diptera : Chironomidae) from SE U.S.A., with descriptions of Plhudsonia, Unniella and Platysmittia n.genera and Atelopodella n.subgen. Ent. scand. 3 : 465-510.

Sæther O.A. 1989. - Phylogenetic trends and their evaluation in chironomids with special reference to orthoclads. $I n$ : Devai, G. (ed) : Advances in chironomidology. Part 1. Act. Biol. Debr. Oecol. Hung 2 : 53-75.
Sather O.A. 1990. - A review of the genus Limnophyes Eaton from the Holarctic and Afrotropical regions. (Diptera : Chironomidae, Orthocladiinae). Ent. scand., Suppl. 35, 135 pp.

Sæther O.A. 1992. - First Palaearctic record of the orthoclad genus Plhudsonia Sæther (Diptera : Chironomidae). Ent. scand. $22: 379-384$.

Sasa M. 1978. - Taxonomical and biological notes on Tokunagayusurika akamusi (Tokunaga), with description of immature states (Diptera, Chironomidae). Jap. J. Sanit. Zool. 29 : 30-101. 